\title{
Production and Characterization of Bacteriocin Produced by Lactobacillus Viridescence(NICM 2167)
}

\author{
Sure KP ${ }^{1}$; Kotnis PV ${ }^{1}$;Bhagwat $\mathrm{PK}^{\mathbf{2}}$; Ranveer $\mathrm{RC}^{\mathbf{1}}$; ${\text { Dandge } \mathrm{PB}^{\mathbf{3}} \text { andSahooAK }}^{\mathbf{4}}$ \\ ${ }^{1}$ Department of Food Science and Technology, ${ }^{2}$ Department of Microbiology; ${ }^{3}$ Department of Biochemistry; \\ ${ }^{4}$ Department of Technology, Shivaji University, Maharashtra, India
}

\begin{abstract}
The present study focused on the production optimization of bacteriocin by Lactobacillus viridescence NICM 2167 followed by its purification and characterization. The bacteriocins are antimicrobial peptides produced by many Gram positive and Gram negative bacteria.The bacteriocin produced by LAB (lactic acid bacteria) received attention in recent years due to their potential application as natural preservatives in food. Bacteriocinproduced by Lactobacillus viridescence showed broad range of antimicrobial activity against food borne pathogens. Production parameters were optimized showing highest production of bacteriocinin MRS broth with $\mathrm{pH}=7.0$ incubated at $37^{\circ} \mathrm{C}$ for $48 \mathrm{~h}$. Bacteriocin was purified in two steps involving ammonium sulphate precipitation followed by gel filtration using Sephadex G-100. Purified bacteriocin with single band on SDS-PAGE showed molecular weight of $8.3 \mathrm{kDa}$. This purified bacteriocin was stable over wide range of $\mathrm{pH}(4-10)$ as well as temperatures $\left(4^{\circ} \mathrm{C}-121^{\circ} \mathrm{C}\right)$ suggesting it as a potent candidate for preservation of various foods.
\end{abstract}

Key words:Lactobacillus viridescenceNICM 2167,bacteriocin, antimicrobial activity, gel filtration

*Author for correspondence: rahul.ranveer@gmail.com 


\section{INTRODUCTION}

Lactic acid bacteria (LAB) are widely used in the food industry as starter culture for fermentation. Lactobacilliare being utilized in against infectious diseases since decades and haveability to protect against many pathogens(Bernet-Camard et al. 1994). The Lactobacilliis widely utilized as a probiotic organism. Many lactic acid bacteria such asLactobacillus, Lactococcus, Streptococcus, Pediococcus, Leuconostocetc are known to produce antibacterial substances including bacteriocins, which can inhibit the growth of several pathogenic bacteria.

Bacteriocins are byproducts of bacterial metabolism. Bacteriocins are agents which are encoded in the genetic material carried by plasmid with the purpose of killing or inhibiting closely related species or even different strains of the same species. Bacteriocins arise from the need for survival in over populated environment or culture. Thus the cells containing encoding for bacteriocins have the capacity of destroying the surrounding cells without the bacteriocin plasmid and the event is compensated by the rate of which the bacteriocin containing cells is able to transpose the plasmids with the required function into other cells. Eventually only cells containing a plasmid encoding bacteriocin will leave in the culture(Avonts and Vuyst 2001).Bacteriocins are antimicrobial peptides and proteins produced by lactic acid bacteria. Although bacteriocins may be found in Gram-positive and Gram-negative bacteria (Riley and Wertz 2002; Nandane et al. 2007), those produced by LAB (Lactic acid bacteria) have received particular attention in recent years due to their potential application in food industry as natural preservatives (Ennhar et al. 1999).

Bacteriocins can be used as food additives like, Nisin produced by Lactobacillus lactis is the beststudied and the only antibiotic approved in more than 60 countries including USA to be used in food industry(Twomey et al. 2002) and a marketed preparation with pediocin PA-1 producer is available(Rodriguez et al. 2002). Several studies have indicated that LAB starter cultures or coculture are able to produce their bacteriocins in food matrices, and consequently display inhibitory activity towards sensitive food spoilage or pathogenic bacteria. The latter trait has mainly been documented for fermented sausages, fermented vegetables and olives and dairy products (Ennhar et al. 1999). Lactobacillusbacteriocins are grouped as class-I characterized. bacteriocins (Lantibiotics), class-II bacteriocins (Heatstable, non-lantibiotics), classIII (heat-labile proteins with large molecular mass) and class-IV (hydrophobic and heat-stable proteins, associated with lipids orcarbohydrates). The antibiotics in general have wider spectrum of activity than the non-antibiotics.

So in the present study attempts have been made to produce, purify and characterize the bacteriocinproduced by Lactobacillus viridescence(NICM 2167).

\section{MATERIAL AND METHODS}

\section{Material \\ Chemicals}

De Man Rogosa Sharpe media, Nutrient broth, Nutrient agar, ammonium sulphate, sodium carbonate, trisodium citrate, copper sulphate, polyphenol reagent, bovine serum albumin, ethanol, $\mathrm{HCl}, \mathrm{NaOH}$, Phosphate buffer were purchased fromHi media, India. All other chemicals used were of analytical grade.

\section{Culture}

Lactobacillusviridescence (NCIM 2167) was procured from National Collection of Industrial Microorganisms (NCIM), Pune and was used for the production of bacteriocin.

\section{Indicator organisms}

To study the effect of the bacteriocin produced by the strain under studyvarious food-borne pathogens and spoilage causing microorganisms like Bacillus cereus(NCIM 2156), Bacillus megaterium(NCIM 2087), Escherechia coli (NCIM 2066), Salmonella typhimurium(NCIM 2501), Pseudomonas aeruginosa(NCIM 2036), Bacillus subtilis(ATCC 6633)and Staphyllococcusaureus(NCIM 2079) were procured from National Collection of Industrial Microorganisms (NCIM), Pune, India.

\section{Bacteriocin assay}

The antibacterial activity of the bacteriocin isolated from Lactobacillus viridescence was determined using the well diffusion method as described by Franz et al. 1996. Wells $(50 \mu \mathrm{L})$ that had been cut in agar plates previously seeded with 
the indicator bacteria. The plates were incubated at $37^{\circ} \mathrm{C}$ for $24 \mathrm{~h}$ and after incubation the diameter of zone of inhibition was measured.

\section{Optimization of production parameters Effect of incubation time on bacteriocin production}

MRS broth was prepared, inoculated with fresh culture of Lactobacillus viridescence and incubated at different incubation time like 24, 48 and $72 \mathrm{~h}$. The growth was measured at $600 \mathrm{~nm}$ and cell free culture medium was used to quantitate protein concentration.

\section{Effect of $\mathrm{pH}$ and temperature on bacteriocin production}

The MRS broth having different $\mathrm{pH} \mathrm{4,} \mathrm{5,} \mathrm{6,} \mathrm{7,} \mathrm{8,} 9$ and 10 were prepared and separatelyinoculated with fresh culture of Lactobacillusviridescence and incubated for $48 \mathrm{~h}$. Similarly for production temperature optimization MRS broth was prepared, inoculated with fresh culture of Lactobacillusviridescence and incubated at different temperatures like $10^{\circ} \mathrm{C}, 20^{\circ} \mathrm{C}, 30^{\circ} \mathrm{C}$, $37^{\circ} \mathrm{C}$ and $45^{\circ} \mathrm{C}$ for $48 \mathrm{~h}$. The growth was measured at $600 \mathrm{~nm}$ and cell free culture medium was used to quantitate protein concentration.

\section{Production of bacteriocin}

Overnight grown culture of

Lactobacillusviridescence (NCIM 2167) was propagated in de Man Rogosa Sharpe broth at 10\% of inoculum volumeand incubated for $48 \mathrm{~h}$ at 120 $\mathrm{rpm}$ at $37^{\circ} \mathrm{C}$.After incubation the whole broth was centrifuged at 11180gfor $15 \mathrm{~min}$ and the cell free supernatant was used as a crude bacteriocin(Ogunbanwo et al. 2003). Protein concentration of the bacteriocin in the sample was determined by the method of Lowry et al. 1951.

\section{Purification of bacteriocin}

The cell free culture supernatant (crude bacteriocin) was saturated with $70 \%$ ammonium sulphate and stored at $4^{\circ} \mathrm{C}$ to precipitate out the proteins. The pellet was collected after centrifugation at $11180 \mathrm{~g}$ at $4^{0} \mathrm{C}$ for $30 \mathrm{~min}$. The pellet was dissolved in $0.1 \mathrm{M}$ phosphate buffer $(\mathrm{pH}$ 7.0) and dialyzed against the same buffer at $4^{0} \mathrm{C}$ overnight [9]. Concentrated bacteriocin sample was further purified by gel filtration using Sephadex G-100. Five gramsof Sephadex G-100 was activated according to the standard procedure.
Further swollen, deaerated gel was packed in column and column is washed with $0.1 \mathrm{M}$ phosphate buffer( $\mathrm{pH}$ 7.0). Concentrated dialyzedbacteriocin sample was loaded on the packed column, then it was eluted with $0.1 \mathrm{M}$ phosphate buffer ( $\mathrm{pH}$ 7.0) and samples fractions of $3 \mathrm{~mL}$ were collected at the rate of $0.25 \mathrm{~mL} / \mathrm{min}$. Protein content of fractions were analyzed by measuring its absorbance at $280 \mathrm{~nm}$ and for bacteriocin plate assay were used. Molecular weight of purified bacteriocin was analyzed by SDS-PAGE analysis with $12 \%$ of resolving gel and $4 \%$ of stacking gel in a midi-electrophoresis equipment along with standard protein markers (Jhample et al. 2015).

\section{Activity assay}

The bactericidal activity of culture supernatant, partially purified, and purified bacteriocin produced by Lactobacillusviridescence (NCIM 2167) was calculated by serial dilution of respective bacteriocin samples. Above mentioned samples were diluted in the range of $10^{-1}$ to $10^{-10}$ and the smallest detectable zone of inhibition corresponding to the diluted bacteriocin was used to calculate AU/mL (Sharma et al. 2011).

\section{Characterization of bacteriocin Effect of pH}

Purified bacteriocin was mixed with equal volume of buffers with $\mathrm{pH}$ values ranging from 4 to 10 , with an increment of 1 and incubated for $30 \mathrm{~min}$ at Room temperature. Bacteriocin samples treated with different $\mathrm{pH}$ values then assayed against indicator bacteria by well diffusion method.

\section{Effect of temperature}

Purified bacteriocin was incubated at different temperatures like 4, 10, 20, 30, 40, 50, 60, 70, 80, 90 and $100^{\circ} \mathrm{C}$ for $30 \mathrm{~min}$ and at $121^{\circ} \mathrm{C}$ for $15 \mathrm{~min}$. Bacteriocin samples treated with different temperatures then assayed against indicator bacteria by well diffusion method.

\section{RESULTS AND DISCUSSION}

Lactobacillusviridescence (NCIM 2167) was selected on the basis of its ability to produce bacteriocin which was active against many potential food pathogens. Bacteriocin production from Lactobacillusviridescence (NCIM 2167) is 
novel source which has not been investigated so far.

Antimicrobial activity of the bacteriocin produced by Lactobacillus viridescence was analyzed by agar well diffusion technique on potential food pathogens. Bacteriocin present in culture supernatant showed the antimicrobial activity against various Gram positive and Gram negative microorganisms. The antimicrobial activity was observed against microorganisms like Bacillus cereus, Bacillus megaterium, Escherichia coli, Staphylococcus aureus and Pseudomonas aeruginosawhereas;AlkaligensfeacalisandBacillus subtilis were not susceptible to it (Table 1).

Table 1- Antimicrobial activity of crude bacteriocin

\begin{tabular}{lc}
\hline \multicolumn{1}{c}{ Test organisms } & $\begin{array}{c}\text { Zone of } \\
\text { inhibiton }\end{array}$ \\
\hline Bacillus cereus & + \\
Bacillus megaterium & + \\
Bacillus subtilis & - \\
Escherichia coli & + \\
Salmonella typhimurium & + \\
Staphylococcus aureus & + \\
Pseudomonas aerugenosa & + \\
Alkaligensfeacalis & - \\
\hline${ }^{6}+$ 'sign shows presence of zone of inhibition; '- \\
sign indicates absence of zone of inhibition)
\end{tabular}

As bacteriocinis peptide in nature various reports reported that protease has ability to degrade bacteriocins(Sharmaetal 2011) But all the indicator organisms tested viz. Bacillus cereus, Bacillus megaterium, Bacillus subtilis, Escherichia coli, Staphylococcus aureus, Pseudomonas aeruginosaandAlkaligensfeacaliscan produce potent protease(Drapeau et al. 1972;Brunder et al. 1997;Anwar and Saleemuddin 1998; Thangam and Rajkumar 2002; Bhagwat et al. 2015).Thus it clearly shows that only few proteases could break down the bacteriocin as per their specificity towards respective bacteriocin. Amongst Escherichia coli showed the better results, hence it is used for further studies.Bacteriocin from culture supernatant showed the total activity of $6.2 \times 10^{8} \mathrm{AU} / \mathrm{mL}$ (Table2). It showed a good antagonistic activity against a number of potent food pathogens, which shows its efficacy and potential application as a natural food preservative. Moreover bacteriocins are supposed to act only on closely related species, which limits their application as a good
preservative(Ceveland et al. 2001). In contrast, our study revealed thatbacteriocin produced from Lactobacillus viridescence was found to be active on various microorganisms suggesting its broad spectrum of activity. Similar results were observed in case ofbacteriocinproduced from Bacillus Subtilis R75 which was found to be active on number of species, thus it proves thatbacteriocins from different microbes have specific inhibition spectra(Sharma et al. 2011).

The protein concentration was found to be more at $48 \mathrm{~h}$ of incubation than 24 and $72 \mathrm{~h}$ of incubation, respectively same results were obtained for growth of Lactobacillusviridescence. Hence, the optimum period of incubation for production is 48 hours (Fig. 1). Similar reports were observed in case of bacteriocin production from Lactobacillus plantarum where optimum period was found to be at $48 \mathrm{~h}$, in contrast production of bacteriocin form Bacillus subtilisR 75 required $72 \mathrm{~h}$ of incubation (Sharma et al. 2011; Amortegui et al. 2014).

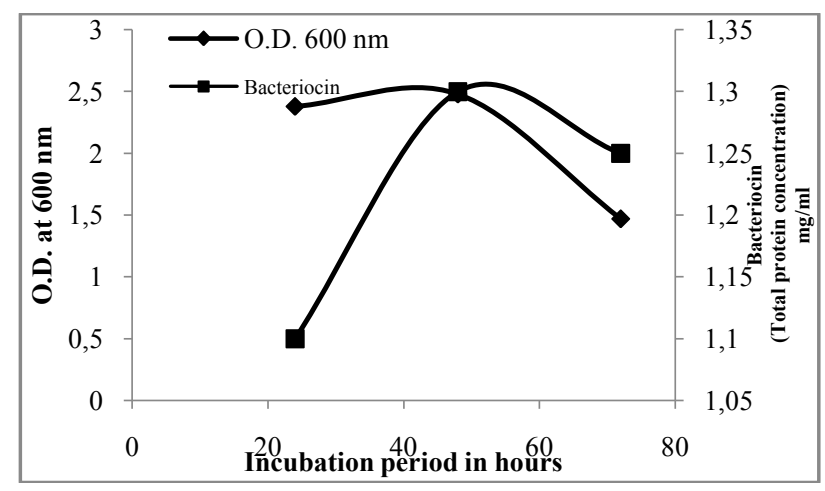

Figure 1 -Effect of incubation period on production of bacteriocin

In $\mathrm{pH}$ optimization studies, the concentration of protein was found to be highest at $\mathrm{pH} 7$, whereas considerable decrease was observed at both acidic as well as alkaline $\mathrm{pH}$ (Fig. 2).

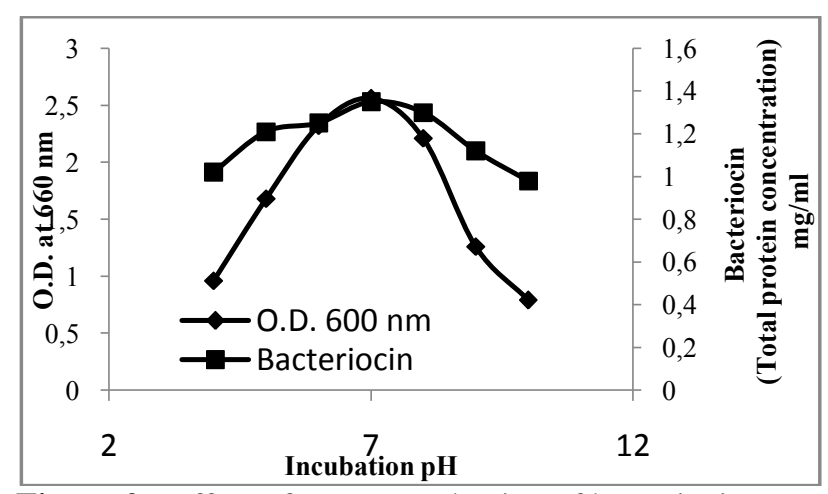

Figure 2 - Effect of $\mathrm{pH}$ on production of bacteriocin 
Most of the reports of bacteriocin production from Lactobacillus showed its production at acidic to slightly neutral range of $\mathrm{pH}$, on the contrary our study stated highest production at neutral range of pH(Deraz et al. 2005; Amortegui et al. 2014). While in case of temperature optimization studies, better results were found at $37^{\circ} \mathrm{C}$ having highest protein content as well as cell biomasssuggestingit as an optimum temperature for the production of bacteriocin. The protein concentration as well as growth at temperature of $10^{\circ} \mathrm{C}$ was very low as compared to others. (Fig. 3) Similar results were observed in case various other microorganisms where bacteriocin production was taken at $37^{\circ} \mathrm{C}$ temperature(Sharma et al. 2011; Amortegui et al. 2014).

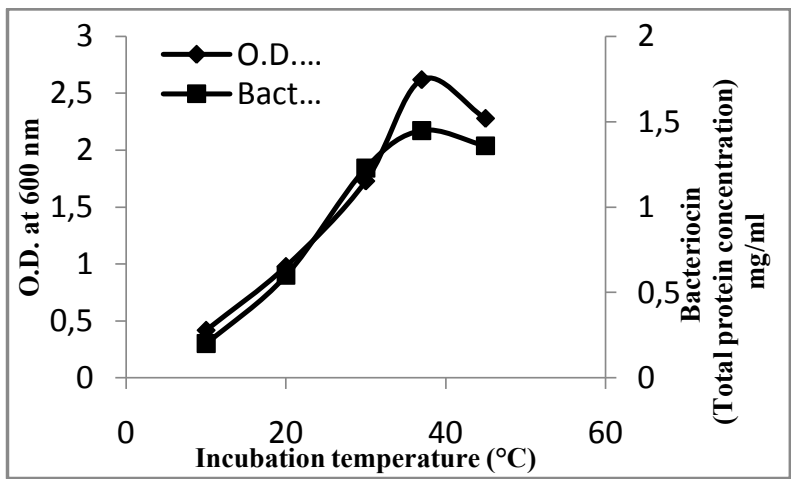

Figure 3 - Effect of temperature on production of bacteriocin

Bacteriocin with wide spectrum of antimicrobial activity was further subjected to purification process. In two step purification process, firstly partial purification was achieved by subjecting cell free supernatant to ammonium sulfate precipitation at $70 \%$. Further purification was carried out by size exclusion chromatography usingSephadex G100.Enhanced activity of partially purified bacteriocin exhibited total activity of $6 \times 10^{7} \mathrm{AU} / \mathrm{mL}$, whereas after complete purification by gel chromatography it showed total activity of
$3 \times 10^{7} \mathrm{AU} / \mathrm{mL}$. In final purification step,active fractions (52-54) were pooled together andwhich showed 4.69 foldpurification of bacteriocin with recovery of $1.032 \%$ (Fig. 4 and Table 2). The purified bacteriocin appeared as a single band in SDS-PAGE with molecular weight ofapproximately $8.3 \mathrm{kDa}$ (Fig. 5).This purified bateriocin showed antimicrobial activity against all the three tested organisms viz, Escherichia coli, Bacillus cereus and Staphylococcus aureus confirming its activity (Fig6). Low molecular weight of purified protein measured in present study is a characteristic feature of bacteriocin.Similarly bacteriocin produced by LactobacillusplantarumST13BR had molecular weight of $9.5 \mathrm{kDa}$ (Sankaret al. 2012). A bacteriocin produced by Bacillus Subtilis R75 had a molecular mass of $12 \mathrm{kDa}$ based on gel filtration analysis(Sharma et al. 2011). The bacteriocins of bacteria belonging to class-I and II have molecular weight $<5 \mathrm{kDa}$ and $<10 \mathrm{kDa}$ respectively hence bacteriocin purified in this study can be called as class-II bacteriocin group(Bodaszewska-Lubas et al. 2012).

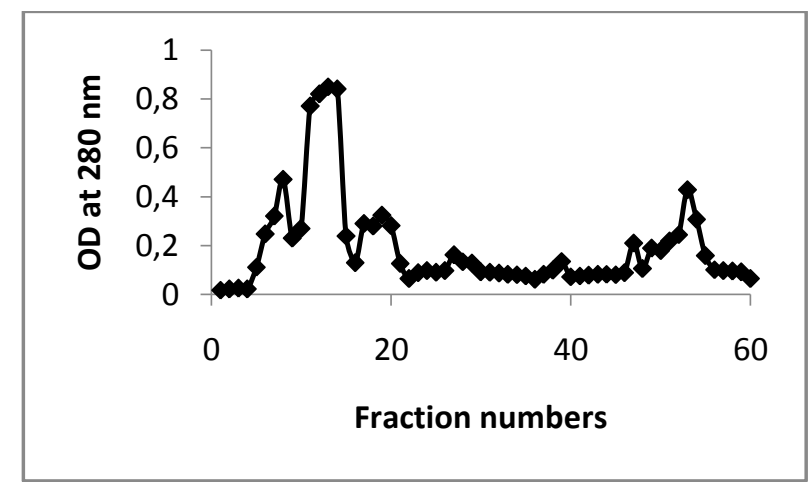

Figure 4 - Elution profile of bacteriocin purification from Lactobacillusviridescence (NCIM 2167)

Table 2- Summary of the purification profile for bacteriocin from Lactobacillusviridescence

\begin{tabular}{lccccc}
\hline Purification steps & $\begin{array}{c}\text { Total activity } \\
(\mathrm{AU} / \mathrm{ml})\end{array}$ & $\begin{array}{c}\text { Total protein } \\
(\mathrm{mg})\end{array}$ & $\begin{array}{c}\text { Specific activity } \\
\left(10^{6}\right)\end{array}$ & $\begin{array}{c}\text { Purification } \\
\text { fold }\end{array}$ & $\begin{array}{c}\text { Recovery } \\
(\%)\end{array}$ \\
\hline $\begin{array}{l}\text { Culture filtrate } \\
\text { Ammonium }\end{array}$ & $6.2 \times 10^{8}$ & 271.2 & 2.28 & 1 & 100.0 \\
$\begin{array}{l}\text { sulfate } \\
\begin{array}{l}\text { Sephadex } \\
\text { G-100 }\end{array}\end{array}$ & $3 \times 10^{7}$ & 25.3 & 2.37 & 1.039 & 9.32 \\
\hline
\end{tabular}




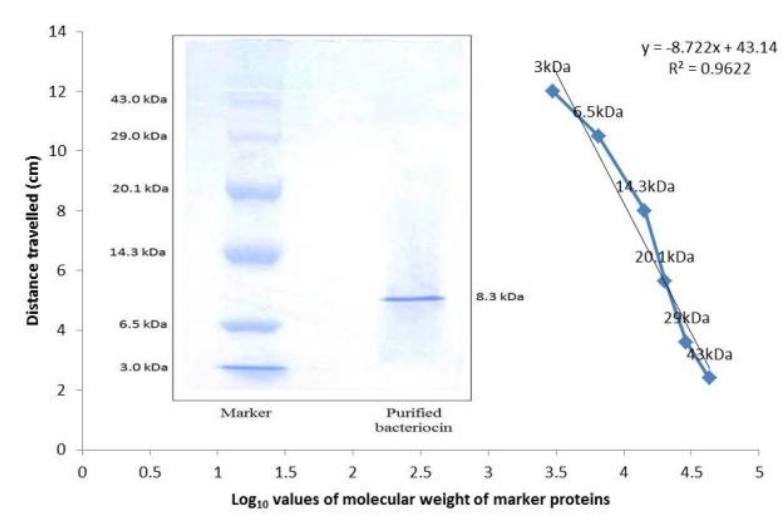

Figure 5- SDS-PAGE analysis of purified bacteriocin

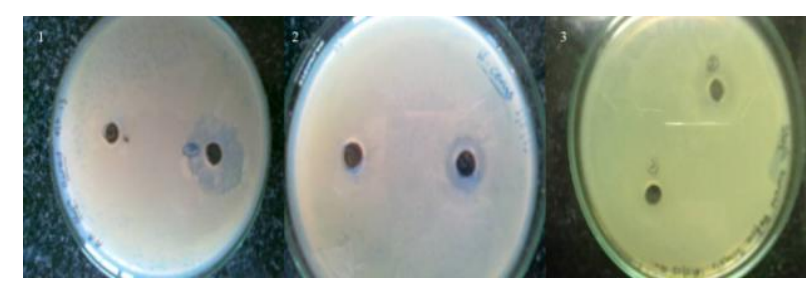

Figure 6 - Antimicrobial activity of purified bacteriocin against 1) Escherichia coli2) Bacillus cereus 3) Staphylococcus aureus

Bacteriocinshave potent applications in preservation of various types of food products and hence purified bacteriocin was further characterized for its efficiency to work under different environmental conditions.In present study purified bacteriocin showed its activity at $\mathrm{pH}$ range of 4 to 10 , but significantly it was active at acidic to neutral range of $\mathrm{pH}$ ranging from 5 to 7 (Fig. 7). Similarly significant activity at pH 6 and 7 was shown in case of bacteriocin produced from Bacillus subtilis R75(Sharma et al. 2011), whereas bacteriocin from LactobacillusplantarumLE5 and LE7 was found to be active at wide range of $\mathrm{pH}$ values ranging from 2 to 12 (Amortegui et al. 2014).In temperature stability studies it was found that purified bacteriocin was stable at wide range of temperatures (Fig. 8). Similar results were shown in case of bacteriocins produced by Bacillus Subtilis R75 as well as LactobacillusplantarumLE5 and LE7 (Sharma et al. 2011; Amortegui et al. 2014).Purified bacteriocin in this study even had shown activity after treatment at $121^{\circ} \mathrm{C}$ which opens an avenue for its use in such food products which needs to be operated at high temperatures.It can also show the activity against food pathogens which are heat resistant and hence could be exploited as a potent source of bacteriocin.

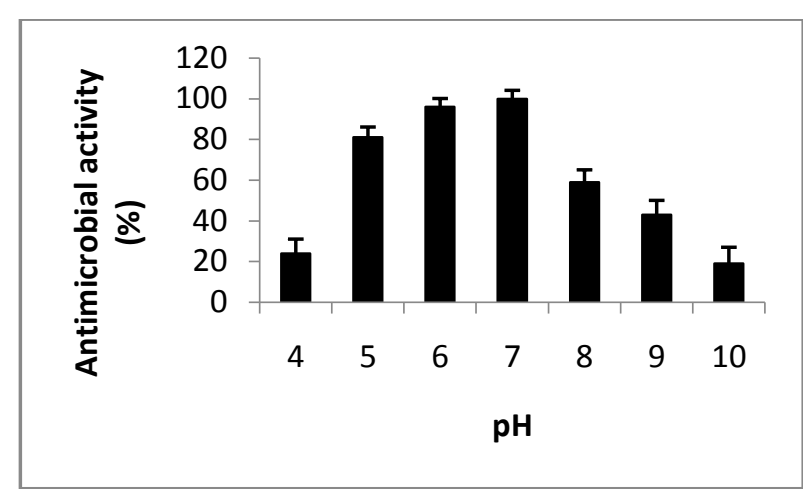

Figure 7- Effect of $\mathrm{pH}$ on the activity of purified bacteriocin.Mean error bars in the graph represent the mean \pm standard error

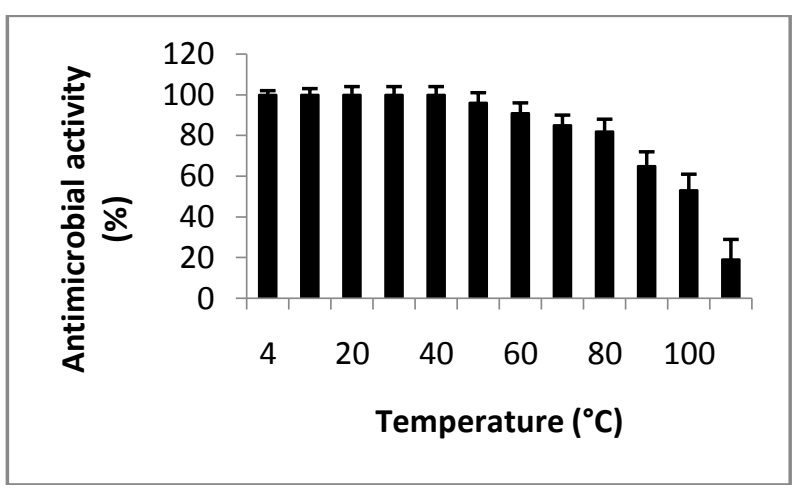

Figure 8 - Effect of temperature on the activity of purified bacteriocin.Mean error bars in the graph represent the mean \pm standard error

\section{CONCLUSION}

In this study we have described complete purification and characterization of newly isolated class II type of bacteriocin from Lactobacillusviridescence (NCIM 2167). In this study optimized production conditions yielded a bacteriocin which was purified at its finest level. Purified bacteriocin was having wide range of physicochemical stabilities as well as it was active against a range of food pathogens. So all these characteristics attributes showed bacteriocin as a new and promising source with multiple future prospective. 


\section{REFERENCES}

Amortegui J, Rodríguez-López A, Rodríguez D, Carrascal AK, Almeciga-Diaz CJ, Melendez AD, et al. Characterization of a new Bacteriocin from Lactobacillus plantarumLE5 and LE27 isolated from Ensiled Corn. App Biochem Biotechnol. 2014;172(7): 3374-3389.

Anwar A, Saleemuddin M. Alkaline proteases: a review. Bioresource Technol. 1998;64(3):175-183.

Avonts L, Vuyst D. Antimicrobial potential of probiotic Lactic acid bacteria. Proc $15^{\text {th }}$ Forum for Applied Biotechnol Gent. 2001; 24-25: 543-555.

Bernet-Camard MF, Liévin V, Brassart D, Neeser JR, Servin AL, Hudault S. Lactobacillus acidophilus LA1 binds to cultured human intestinal cell lines and inhibits cell-attachment and cell-invasion by enterovirulent bacteria. Gut.1994; 35: 483-489.

Bhagwat PK, Jhample SB, Dandge PB. Statistical medium optimization for the production of collagenolytic protease by Pseudomonas sp. SUK using response surface methodology. Microbiol. 2015; 84:520-530.

Bodaszewska-Lubas M, Brzychczy-Wloch M, Gosiewski T, Piotr BH. Antibacterial Activity of Selected Standard Strains of Lactic Acid Bacteria Producing Bacteriocins-Pilot Study. Postepy Hig Med Dosw. 2012; 25: 787-794.

Brunder W, Schmidt H, Karch H. EspP. a novel extracellular serine protease of enterohaemorrhagic Escherichia coli $0157: \mathrm{H} 7$ cleaves human coagulation factor V. Mol Microbial. 1997; 24(4): 767-778.

Ceveland J, Montville TJ, Nes IF, Chikindas ML:Bacteriocins: safe, natural antimicrobials for food preservation. Int J Food Microbiol. 2001; 71:1-20.

Deraz SF, Karlsson EN, Hedstrom M, AnderssonMM,MattiassonB. Purification and characterization of acidocin D20079, a bacteriocin produced by Lactobacillusacidophilus DSM 20079.J Biotechnol. 2005; 117:343-354.

Drapeau GR, Boily Y, Houmard J. Purification and properties of an extracellular protease of Staphylococcus aureus. J Biol Chem. 1972; 247(20): 6720-6726.

Ennhar S, Sonomoto K, Ishizaki A. ClassIIabacteriocins from lactic acid bacteria: antibacterial activity and food preservation. J Biosci Bioeng.1999; 87:705-716
Franz CMAP, Schillinger U, Holzapfel WH. Production and characterization of enterocin 900, a bacteriocin produced by Enterococcusfaecium BFEE 900 from black olives.Int J Food Microbiol.1996; 29:255-270.

Jhample SB, Bhagwat PK, Dandge PB. Statistical media optimization for enhanced production of fibrinolytic enzyme from newly isolated Proteus penneriSP-20. Biocatal Agric Biotechnol. 2015 (In press).

Lowry OH, Rosebrough NJ, Farr AL, Randall RJ. Protein measurement with the Folin phenol reagent. $J$ Biol Chem. 1951; 193(1):265-275.

Nandane AS, Tapre AR, Ranveer RC. Applications of Bacteriocins as bio-preservatives in foods: A review, ADIT J of Engg. 2007; 4(1): 50-55.

Ogunbanwo ST, Sanni AI, Onilude AA. Characterization of bacteriocin produced by Lactobacillus plantarum F1 and Lactobacillus brevis OG1. Afr J Biotechnol. 2003; 2(8): 219-227.

Riley MA, Wertz JE.Bacterocins: Evolution, ecology and application. Ann Rev Microbiol. 2002; 56:117137.

Rodriguez JM, Martinez MI, Kok J.Pediocin PA-1, a side spectrum bacteriocin from lactic acid bacteria.Crit Rev Sci Nutr. 2002; 42:91-121.

SankarNR, Priyanka VD, ReddyPS, Rajanikanth P, Kumar VK, Indira M. Purification and characterization of bacteriocin produced by Lactobacillus plantarum isolated from cow milk. Int J Microbiol Res. 2012; 3(2): 133-137.

Sharma N, Kapoor R, Gautam N, Ranjana K. Purification and characterization of bacteriocin produced by Bacillus subtilis R75 isolated from fermented chunks of mung bean (Phaseolusradiatus). Food Technol Biotechnol. 2011; 49(2):169.

Thangam EB, Rajkumar GS. Purification and characterization of alkaline protease from Alcaligenesfaecalis. Biotechnol Applied Biochem. 2002; 35(2):149-154.

Twomey D, Ross RP, Ryan M, Meaney B, Hill C. Lantibiotics produced by lactic acid bacteria: Structure, function and applications.Antonie Van Leeuwenhoek. 2002; 82: 165-185.

Received: August 31, 2015; Accepted: December 16, 2015. 